\title{
Destroying the National-Spiritual Values of Ukrainians during the Anti-Religious Offensive of the Soviet Totalitarian State in the 1960s and 1970s
}

\author{
Niszczenie wartości narodowo-duchowych Ukraińców \\ podczas anty-religijnej ofensywy sowieckiego państwa totalitarnego \\ w latach 60. i 70. XX wieku
}

\section{- Abstrakt •}

Artykuł zajmuje się kościelnym i religijnym życiem Ukraińców w kontekście narodowościowych i politycznych procesów mających miejsce w latach 60. i 70. XX wieku. Autorka prezentuje charakterystykę anty-religijnej polityki rządu radzieckiego, pokazuje jej kierun$\mathrm{ki}$, formy i metody, bada stosunek przedstawicieli tytularnego narodu wobec prześladowań religijnych i manipulacji świadomością religijną przez przywódców komunistycznych i podkreśla kompleksowość działań ateizacyjnych i eliminację możliwości odrodzenia religijności wśród ludzi. Autorka odsłania istotę, proces tworzenia i sztucznego egzekwowania nowego radzieckiego rytualizmu w życiu Ukraińców. Ten rytualizm stał się wygodnym narzędziem do popularyzacji ideologii komunistycznej w Ukraińskiej SRR, niszcząc pamięć historyczną i osłabiając tożsamość narodową narodu ukraińskiego. Nowy radziecki rytualizm był również narzędziem do realizacji polityki denacjonalizacji Ukraińców, poczynając od odwiecznego zwalczania ukraińskich zwyczajów, tradycji i rytuałów. Model polityki pań-

\section{- Abstract •}

The article deals with the church and religious life of Ukrainians in the context of national and political processes during the 1960s and 1970s. The author characterizes the anti-religious policy of the Soviet government, shows its directions, forms, and methods, studies the attitude of Ukraine's title nation representatives to religious persecution and to manipulation of religious consciousness by the communist leadership, and highlights comprehensive atheistic activities and the elimination of the ways for reviving religiosity among people. The author reveals the essence, the process of creating and artificially enforcing the new Soviet ritualism in Ukrainians' lives. This ritualism has become a convenient tool for popularizing communist ideology in the Ukrainian SSR, destroying historical memory and undermining the national identity of the Ukrainian people. The new Soviet ritualism was also a means for implementing the policy of denationalizing Ukrainians, beginning with the age-old religious oppression of Ukrainian customs, traditions, and rituals. The model of state-church policy of the Soviet 
stwa wobec wspólnot religijnych reprezentowany przez władze radzieckie w omawianym okresie był oparty na wykorzystywaniu różnorodnych form i metod walki z religią, włączając w to: kompleksową kontrolę nad działalnością duchowieństwa, niszczenie miejsc kultu religijnego i obiektów sakralnych, a także wywieranie administracyjnej, moralnej i politycznej presji na wierzących. Wypierając religię, radzieckie państwo totalitarne niszczyło nie tylko rodzime zwyczaje religijne narodu ukraińskiego, ale również podminowywało fundamenty wielowiekowej kultury i osłabiało narodową odrębność Ukraińców.

Słowa kluczowe: ukraińskie wartości narodowo-duchowe, stosunki państwo-Kościół na Ukrainie, kampania antyreligijna, opozycja, prześladowanie religijne, propaganda ateistyczna, państwo totalitarne power in the described period was based on the use of a variety of forms and methods of struggle against religion, including: a comprehensive control over clergy activities, destruction of religious sites and sacred objects, as well as administrative, moral, and political pressure on believers. Displacing religion, the Soviet totalitarian state destroyed not only native religious customs of the Ukrainian people, but also violated the principles of the centuries-old traditional culture and undermined the national fortitude of Ukrainians.

Keywords: Ukrainian national-spiritual values, Ukrainians' state-church relations, anti-religious campaign, opposition, religious oppression, atheistic propaganda, totalitarian state

\section{Formulation of Scientific Problem and Its Significance}

Religion and the institution of church have always been a spiritual and ideological factor of consolidating the Ukrainian nation; it served as a means of national selfexpression and traditionally played an important role in the cultural, social, and political life of Ukrainians. However, the religious sphere in the Soviet Ukraine period was suddenly broken by atheism. It rejected everything that has been traditional in the Ukrainian society for centuries. The eradication of the Christian worldview began. In this context it should be noted that the 1960s and the 1970s were characterized by the destruction of religious consciousness and religious worldview of Ukraine's title nation, the review of ideas about the church, the closing of churches, and the national oppression of Ukrainian authenticity and identity. The concept of Christian morality was not included into the ideological framework of the ruling party system. Communist authorities directed all their efforts to destroy the church as a social institution, which led to deep strains in public and personal spheres of the Ukrainian people's lives. The Soviet times were a cruel test of strength of the Ukrainian national character and its capacity for an independent state-building.

The Ukrainian state gained its independence. It caused a democratization of the political life of the society, opened access to many archival sources, and created favorable conditions for free, fair, considerate, and methodological study of the 
Soviet past of the Ukrainian people as well as rethinking their history, especially the history of the church.

Nowadays there is an increase of public interest in religion as an insufficiently studied socio-cultural phenomenon. A comprehensive study of religious issues, such as the national-spiritual values of Ukrainians during the anti-religious offensive of the Soviet totalitarian state in the 1960s and 1970s always retains its relevance and interest of researchers and requires a special approach in the study. A thorough analysis of atheistic propaganda during this period gives an opportunity to understand and explore the modern, post-atheistic period and to find answers for many questions that arise as a result of the reduction of religiosity among the people of independent Ukraine.

\section{Research Analysis}

The Ukrainian people's church and religious life in the second half of the $20^{\text {th }}$ century is partially explored in the papers of such authors as: I. Andrukhiv (2011), V. Baran and V. Danylenko (1999), V. Vovk (2007), G. Marynchenko (2013), V. Marchuk (2004), A. Mykhalchuk (2008), V. Pashchenko (2001), P. Slobodianiuk (2000), A. Tievikova (2007), and others.

The scientists only studied some aspects of the issue, including: an overall description of the atheization of Ukraine during the Soviet period, the study of antireligious propaganda by means of film and radio in the period of the Khrushchev's Thaw, the analysis of legal guarantees of freedom of conscience and religion by the communist regime, the study of the emergence of religious non-conformism, and the clarification of church-state relations and the status of certain denominations in the outlined period. However, the issue remains not studied enough in scientific literature. This enables us to continue working in this perspective area.

\section{The Aim of the Article}

Thus, the focus of this article are: the destruction of national-spiritual values of Ukrainians during the anti-religious offensive of the Soviet totalitarian state in the 1960s and 1970s, the struggle of the Soviet government against church institutions, the attitude of Ukraine's title nation's representatives to anti-religious campaign in the republic, and the influence of the religious factor on Ukrainians' national self-identity in the outlined period. 


\section{The Main Material and Justification of Study Results}

In times of the totalitarian regime in the Ukrainian SSR the struggle for influence on Ukrainians' consciousness was one of the main political directions of the Soviet authorities. That is why the Communist Party directed their political activities against the church as an centuries-old integral part of the Ukrainian people's spiritual life. The religious issue was very important for the Ukrainian SSR leadership. In 1961 the ruling party declared the policy of "building a communist society", which did not provide space for religion. It was the destruction of the religious consciousness of Ukraine's title nation's representatives, the artificial substitution of communist ideology for religion, and the unification of social, political, church and religious life of Ukrainians according to common Soviet models.

The religious palette in Ukraine in the 1960s consisted of about 40 religious denominations (The Issues of Scientific..., 1963, p. 394). The Russian Orthodox Church took a dominant position in the republic. The Russian Orthodox Church operated legally and was supported by the government. Other church communities were considered sectarian groups. The Soviet government tried to strengthen the position of the Russian Orthodox Church, especially in the western region of Ukraine dominated by Greek Catholics. In Ivano-Frankivsk region as of 1 November 1963, 55 former priests of the Greek Catholic Church refused to move into the Orthodox faith and continued their religious activities. That is why they suffered persecution and oppression (State Political Publishing House..., 1962, p. 96).

The Ukrainian Greek Catholic Church continued its development in the underground in order to maintain support for Ukrainians' national consolidation in times of religious persecution. The process of the return of the priests forced to accept orthodoxy started on the initiative of the underground head of the Ukrainian Greek Catholic Church V. Velychkovsky. "Velychkovsky called certain priests to break with orthodoxy and move to the side of the Vatican" - reported the commissioner of the committee for the Russian Orthodox Church in Kiev V. Sukhorin with concern (April, 1964; Marchuk, 2004, p. 244). At the end of the 1960s, 144 Greek Catholic priests and more than 200 monks from liquidated monasteries lived in Lviv (Marchuk, 2004, p. 246). Under these circumstances government institutions made a number of important decisions concerning the struggle against "illegal activities of Uniate churches and sects" and Ukrainian religion in general. In 1969 the bishop V. Velychkovsky was arrested. Famous priests P. Gorodotsky and R. Bakhtalovsky were arrested in Lviv and Kolomyia. Searches in the bishop V. Sterniuk's and dozens of other priests and monks' apartments were made (Marchuk, 2004, p. 247). Many churches were removed from the registry. 
The offensive on religion has been continued over the next years. The Committee for State Security of the USSR widely applied provocations to discredit the Greek Catholic hierarchy. The Soviet authorities developed anti-religious, especially anti-Uniate, museums and galleries in 70 closed churches of the western region to make an ideological influence on the Ukrainian people (Pashchenko, 2001, p. 306). Unauthorized opening of Uniate churches was punishable by up to 10 years of imprisonment (Marchuk, 2004, p. 247). The ideological clichés about "anti-social criminal activities of Uniates" and "their ties with Ukrainian bourgeois nationalists and Nazi punitive bodies" were propagated in the mass-media and some scientific journals (Andrukhiv, 2006, p. 25). Regarding the awakening of national consciousness as a direct threat to the existence of totalitarian communist regime, the Soviet authorities used arrests and other repressive actions (Marchuk, 2004, p. 248). Despite the oppression and persecution, the Ukrainian Greek Catholic Church continued their opposition activities and raised the religious consciousness level of Ukrainians preparing them for practical work in the field of nation-building. In Western Ukraine in general there was a higher degree of religiosity and conventional religious traditions in comparison with other regions of the republic during the studied period. Thus, the anti-religious campaign had a mass scale here.

A large-scale anti-religious struggle was also carried out against various illegal Protestant communities, especially the communities of Evangelical ChristiansBaptists, Pentecostals, Jehovah's Witnesses, and others. In 1962 there were 560 communities (14 470 persons; Bondarchuk et al., 2012, p. 164). They were attributed to religious sacrifice, accused of sexual perversion and espionage, publicly ridiculed, and called criminals and mentally ill (Bondarchuk et al., 2012, p. 166). Between 1961 and 196474 believers were convicted in the Transcarpathian region, 29 - in the Rivne region, 24 - in the Odessa region, 25 - in the Kharkiv region, and 20 - in the Chernivtsi region (Slobodianiuk, 2000, p. 161). Religious belief in the totalitarian state was considered a criminal offense.

The Communist government implemented the new legislation on cults, which legally secured a total attack on religion and violated the constitutional rights of believers. These were the resolutions of the Central Committee of the Communist Party of the Soviet Union On the goals of party propaganda in modern conditions (9 January 1960) and On measures to eliminate violating Soviet legislation on cults by the clergy (13 January 1960; on 19 March 1960 the similar resolution was adopted by the Central Committee of the Communist Party of Ukraine), the resolution of the Minister Council of the USSR On strengthening control over the implementation of legislation on cults (16 March 1961; on 29 April a similar decree was 
adopted by the government of the Ukrainian SSR), the resolution of the Central Committee of the Communist Party of Ukraine On the state and measures to improve scientific and atheistic education of workers in the Ukrainian SSR (9 October 1962), and others (Proceedings No. 26 of the Meeting...,1962, pp. 31-36). The aforementioned legislative decisions of the communist authorities contributed to the reduction in the number of religious institutions and priests, the removal of religious associations from registration, the closing of monasteries, the reduction of the list of sacred monuments by half, and the destruction of a large number of chapels and roadside crosses (Information of the Departments..., 1967, p. 168).

For example, in the report of the commissioner of the Russian Orthodox Church in the Stanislav region On roadside crosses (July 20, 1961) it was stated that 890 commemorative crosses and 93 chapels considered "religious remnants" had been removed on the territory of 12 districts during six months (Andrukhiv et al., 2011, p. 22). Many of these "remnants" had not only religious, but also historical significance, because they were symbols of the abolition of serfdom, the $950^{\text {th }}$ anniversary of the baptism of Rus-Ukraine, the memory of Ukrainian Sich Riflemen and other important events. However, they were considered "visible church propaganda" and subject to liquidation. Defunct churches were reorganized into cultural institutions (clubs, cinemas, gyms) or warehouses for storing fuels, fertilizers, coal, grain, and other agricultural products. Other churches were left empty and destroyed.

The next stage of total atheization of Ukraine's title nation and the struggle for eradicating any demonstration of religiosity in Ukrainians' lives was the creation and artificial introduction of the so-called new Soviet ritualism, which was designed to speed up the implementation of the Soviet policy of denationalizing Ukraine's title nation and forming a model of a Russified Soviet citizen without national identity. It was based on the principles of the communist ideology, which glorified the existing state system and reflected material and spiritual values inherent in the mentality of the Soviet people, causing destruction of age-old traditional customs and rituals of Ukrainians. The Ukrainian native church-religious and folk customs were traditionally interpreted as "remnants", archaic and even reactionary elements of the Soviet life. "... Ukraine has become a springboard for the most brutal internationalization: defamation and prohibition of our customs and rituals, language, songs, religion, life, morality and common law - just what Ukrainian people traditionally lived and were proud of" (Kryvchyk et al., 2003, p. 87).

Religious holidays were officially opposed to new Soviet holidays: anniversaries of collective and state farms, work and harvest holidays, the anniversary of the October Revolution, Lenin's birthday, the day of the Soviet Army, and others. It 
should be emphasized that the Soviet rites were rarely held in Ukrainian language. Celebrations in the Ukrainian SSR and other republics were similar and limited to setting state flags and solemn oaths of allegiance to communist ideas and the cause of the Communist Party (Onufriychuk, 2015, p. 93).

However, Ukrainians continued to celebrate major religious holidays - Palm Sunday, Easter, Christmas, Epiphany, Trinity, and others, regardless of the dominant atheistic ideology. Considering this fact, it was noted in the resolution On the goals of party propaganda in modern conditions (9 January 1961), that local party organizations did not react properly to demonstration of nationalism and cosmopolitanism. "They sometimes take a passive stance towards antagonistic to Marxism Leninism, idealistic, religious ideology"; that is why local party officials were required to strengthen the struggle against religious remnants (Andrukhiv et al., 2011, p. 19). For example, the Soviet leadership saw demonstration of "bourgeois nationalism" in Ukrainian Christmas carols and New Year songs. On 20 December 1972 the Committee of State Security at the Minister Council of the Ukrainian SSR reported "top secretly" to the Central Committee of the Communist Party of Ukraine that "some nationalist individuals, mostly among former members of the choir 'Homin', took measures to hold so-called 'Christmas carols'... as one of the legal forms of engaging new people to the "Ukrainian movement..", because of the phrase in the text of one of the carols: "Lord, give freedom to Ukraine!" (Danylenko, 2013, p. 344). Thus, the Committee of State Security at the Minister Council of the Ukrainian SSR considered it necessary to take measures to prevent possible attempts to use carols for Ukrainian nationalists' antagonistic purposes (Danylenko, 2013, p. 345).

Soviet ritualism with its distinct character of atheism was popularized by communist ideologists by means of the mass-media. Radio and newspapers did everything to "expose the reactionary essence of religion and sectarianism, equip workers with materialistic understanding of natural and social phenomena" (Reports of Regional Committees..., 1969, p. 19). The most popular atheist radio programs imposed on Ukrainians were Let's talk about marriage and wedding ceremonies, How I broke with religion, Belief in divination and its harmfulness, Science of the origin of life on Earth, Religious holiday "Easter" and its essence, The strength is not in God, but in a man, Communist and religious moralities, etc. (Marynchenko, 2013, p. 144).

Film studios were also involved in the anti-religious campaign. For example, the Dovzhenko Odessa Film Studio produced a number of short films that ridiculed religious narrow-mindedness, vanity, and superstition (Reports of Regional Committees..., 1967, p. 28-29). Atheistic worldview was actively popularized by 
employees of regional and national TV. Following the instructions of the leadership, all television studios presented a documentary film entitled Why I stopped believing in God (Vovk, 2007, p. 166). Atheistic feature films were often shown, including: It confuses all (1960, film director - D. Musatova), People with black souls (1961, film director - P. Shamshur), The End of the World (1962, film director - B. Bunyeyev), Confession (1962, film director - V. Voronin), Armageddon (1962, film director - M. Izrailiev), Sinner (1962, film directors - F. Filippov, G. Yegiazarov), All remains to people (1963, film director - G. Nathanson), and others (Marynchenko, 2013, p. 142). According to the Institute for the Study of the USSR, 70 films of anti-religious content were shown in the country in the early 1960s (Marynchenko, 2013, p. 143).

The number of books, brochures, montages, and art exhibitions of anti-religious nature distributed among Ukrainians by means of libraries was constantly growing. In addition, there were atheist corners in houses of culture and clubs, as well as in places of public entertainment. The repertoire of amateur groups consisted of poems and stories that revealed the reactionary essence of religion. The party leadership tried to bring up each Ukrainian as a builder of communism with a new communist morality. Much attention was paid to young people. Schools and all educational institutions were subject to comprehensive atheization. The ground for forming a materialist worldview was placed in primary school textbooks. The leisure of Ukrainian pupils was diversified by means of lectures and evenings devoted to scientific and atheistic issues, including films and slides (Reports of Regional Committees..., 1967, pp. 21-22). Teachers had to carry out anti-religious work not only during the class but also in off-hour time, including organizing atheistic excursions, speaking to religious parents, and holding conversations of anti-religious character. A special "basic atheism" course for students was introduced. For example, the Vinnytsia Pedagogical Institute opened a new civil specialty - atheist lecturer (March, 1959; Vovk, 2007, p. 168). These facts confirm the existence of a whole system of actions aimed at destroying the religious outlook of the young Ukrainian generation and removing the church from the education system.

If atheistic propaganda did not work, the current party leadership started applying repressions. People were fired from their jobs because of their religious beliefs, they were threatened with administrative sanctions, called criminals and often deprived of parental rights (Baran, et al., 1999, pp. 113-114). For example, the report on assistance to local Soviet authorities in the Ivano-Frankivsk region appealed to strengthen control over the implementation of the legislation on cults (March, 1965). The same report stated that 31 parents in the Ivano-Frankivsk region had been deprived of parental rights, because their children did not vis- 
it school for religious reasons (Reports of Regional Committees..., 1965, p. 6). As a result, these pupils were sent to boarding schools.

The religious discrimination of Ukrainians caused many complaints and applications to the central party and government institutions. Most applications were signed by dozens, hundreds or even thousands of indignant believers (The Register of Believers Complaints..., 1965). In the late 1970s 639 families of the Pentecostals in the Ukrainian SSR appealed to the higher authorities with petitions about the permission to move to any non-socialist country (Andrukhiv, 2006, p. 30). The reason for their decision was a rough violation of Art. 52 of the Constitution of the USSR "On freedom of conscience and religion".

\section{Conclusions}

Thus, the following conclusions can be drawn. During the 1960s and 1970s Ukrainians suffered many religious repressions and modernization of different church-religious life aspects. The Soviet government conducted a deliberate policy of eliminating the church life of the Ukrainian people, ignored centuriesold Ukrainian historical traditions, and tried to destroy the Ukrainian clergy. It resulted in mass closure of churches, monasteries, places of worship, centers of spiritual education. The new atheistic, anti-religious ideology was intensively propagated. This ideology interpreted the church as a "remnant" of the pre-Soviet era. Ukrainian religious beliefs considered to be a criminal offense in the totalitarian state.

However, the Soviet leadership could only weaken the Ukrainian religious life, but not completely destroy it. Opponents of the communist ideology and the administrative system as well as representatives of Ukraine's title nation wrote numerous petitions and complaints to the highest state court and organized nonstop vigils near monasteries and temples. Forced atheization of Ukrainians did not produce the expected results. Family traditions of religious education were much stronger for Ukrainian people than communist ideology and scientific atheism. The representatives of Ukraine's title nation kept believing. Closing religious communities determined their secret functioning. Ukrainians secretly visited churches and priests continued their illegal pastoral activities. Religious Ukrainian opposition during the 1960s and the 1970s contributed to the emergence of religious nonconformity and the next stage of the struggle for democratization and independence of the Ukrainian people. 


\section{References:}

Andrukhiv, I. O. (2006). The Policy of the Soviet Power in Religion and Religious Life in the Precarpathian Region in the 1940s and 1980s: Historical and Legal Analysis. Uzhgorod: Publishing House of the Uzhgorod National University.

Andrukhiv, I. O., Kalyuzhny, R. A., Shevchenko, A. Ye. (2011). The Policy of the Soviet Power in the Sphere of Religion in Western Ukraine in the early 1960s. Law Bulletin. Kiev: Publishing House of the Kiev National Aviation University, 3, 19-23.

Baran, V., Danylenko, V. (1999). Ukraine during the Systemic Crisis (1946-1980s). Kiev: Alternatyvy.

Bondarchuk, P., Danylenko, V. (2012). Specificity of the Religious Situation in the Ukrainian SSR (the middle 1950s - the early 1960s). Scientific Bulletin of Vasyl Sukhomlynsky Mykolayiv National University. Mykolayiv: Publishing House of the Vasyl Sukhomlynsky Mykolayiv National University, 3.33, 158-171.

Danylenko, V. M. (eds.). (2013). Political Protests and Nonconformism in Ukraine (1960-1990): Documents and Materials. Kiev: Smoloskyp.

Information of the Departments of the Central Committee of the Communist Party of Ukraine, Reports of Regional Committees of the Communist Party of Ukraine, the Commissioner Council for the Russian Orthodox Church at the Minister Council of the USSR on the Ukrainian SSR, the Commissioner Council for Religious Affairs of the Russian Orthodox Church in the Ukrainian SSR on Churches, Religious Holidays, Sectarian Religious Organizations etc. (1967). Fund 1. Description 24. Case 4494. The Central State Archive of Public Organizations of Ukraine. Kyiv.

Kryvchyk, G., Shcherbakov, A., Yavorski, Yu. (2003). Introducing New Festivals and Ceremonies in the Ukrainian Village during the 1960s and 1980s: Achievements and Distortions. Scientific Notes of Mykhailo Kotsiubynsky Vinnytsia State Pedagogical University: Collected Scientific Papers in History. Vinnytsia: Publishing House of the Mykhailo Kotsiubynsky Vinnytsia State Pedagogical University, VI, 86-93.

Marchuk, V. V. (2004). Church, Spirituality, Nation. The Ukrainian Greek Catholic Church in Public Life of Ukraine in the XXth Century. Ivano-Frankivsk: Plai.

Marynchenko, G. M. (2013). Anti-religious Propaganda by Means of Film and Radio during the Khrushchev's "Thaw" (Based on Materials on the Southern Regions of the Ukrainian SSR). Scientific Bulletin of Vasyl Sukhomlynsky Nikolaev National University. Nikolaev: Publishing House of the Vasyl Sukhomlynsky Nikolaev National University, $3.35,142-146$.

Mykhalchuk, O. (2008). The Attitude of Soviet Authorities to the Orthodox Church during the 1960s and 1980s. Actual Issues of Ukrainian State-Building: Collected Materials of the Regional Scientific Conference (Lutsk, November 16-17, 2007). Lutsk: Publishing House of the Lutsk National Technical University, 141-149.

Onufriychuk, K. (2015). Historiography of Studying Ukrainian Urban Marriage Ceremony (1950s-1980s). Folk Art and Ethnology. Kiev: Publishing House of the Maksym Rylsky Institute of Art Studies, Folklore and Ethnology at the National Academy of Sciences of Ukraine, 2, 93-103. 
Pashchenko, V. O. (2001). The Orthodoxy in the Modern History of Ukraine. Poltava: Publishing House of the Vladimir Korolenko Poltava National Pedagogical University.

Proceedings No 26 of the Meeting of the Central Committee of the Communist Party Presidium October 9, 1962. (1962) Fund 1. Description 6. Case 3421. Kyiv: The Central State Archive of Public Organizations of Ukraine.

Reports of Regional Committees of the Communist Party of Ukraine "On Facts of Irresponsibility in Radiobroadcasting”. (1969). Fund 1. Description 70. Case 242. Kyiv: The Central State Archive of Public Organizations of Ukraine.

Reports of Regional Committees of the Communist Party of Ukraine on Scientific Atheistic Propaganda. (1967). Fund 1. Description 70. Case 2387. Kyiv: The Central State Archive of Public Organizations of Ukraine.

Reports of Regional Committees of the Communist Party of Ukraine on Status and Prospects of Cultural Workers Training in Culture Colleges and Process of Club Building. Reports of the Commissioner Council for the Russian Orthodox Church at the Minister Council of the USSR on the Ukrainian SSR on Enrolling at Theological Seminaries, Celebrating Religious Holidays etc. January 4, 1965 - December 22, 1965. (1965). Fund 1. Description 70. Case 2570. Kyiv: The Central State Archive of Public Organizations of Ukraine.

Slobodianiuk, P. (2000). The Ukrainian Church: the History of Ruin and Revival. Khmelnytsky: [n.p.].

State Political Publishing House of the Ukrainian SSR. (1962). The Communist Party of the USSR and the Soviet State on Religion and Atheistic Propaganda: Collected Documents and Materials. Kiev: State Political Publishing House of the Ukrainian SSR.

The Issues of Scientific and Atheistic Propaganda. The Issues of Religion, Churches and Prayer Houses. The Issues of the Commissioner Council for Religious Affairs of the Russian Orthodox Church in the Ukrainian SSR. (1963). Fund 1. Description 24. Case 2741. Kyiv: The Central State Archive of Public Organizations of Ukraine.

The Register of Believers Complaints and Applications 1964-1965. (1965). Fund 4648. Description 1. Case 443. The Central State Archive of Supreme Bodies of Power and Government of Ukraine. Kyiv.

Tievikova, O. (2007). Religious Life in Ukraine in 1953-1964: Periodization of Historiographical Sources. History of Religions in Ukraine: Research Yearbook. Lviv: Logos, I, 860-868.

Vovk, V. M. (2007). Life and Leisure of Urban Ukrainians during the 1950s and 1980s. Pereyaslav-Khmelnytsky: Publishing House of the Grygorii Skovoroda PereyaslavKhmelnytsky State Pedagogical University. 